JASEM ISSN 1119-8362

All rights reserved
Full-text Available Online at www.bioline.org.br/ja
J. Appl. Sci. Environ. Mgt. June, 2006

Vol. 10 (2) 91 - 93

\title{
Effects of Crude Oil and Oil Products on Growth of Some Edible Mushrooms
}

\author{
*ADEDOKUN, O M; ATAGA, A E \\ Department of Plant Science and Biotechnology, Faculty of Science, University of Port-Harcourt, Rivers State, Nigeria.
}

\begin{abstract}
The vegetative growth response of three local edible mushrooms: Pleurotus pulmonarius (Pp), Pleurotus tuber-regium (Pt) and Lentinus squarrosulus (Ls) on different concentrations of Crude oil (COIL), Automotive Gasoline Oil (AGO), Fresh Engine Oil (ENGOIL) and Spent Engine Oil (SENGOIL) was investigated. The result showed variable degree of sensitivity of the three mushrooms to each of the pollutants at different concentrations used. Pleurotus tuber regium grew fastest among the three organisms on all pollutants and radial growth was observed at all concentrations. Almost the same pattern of growth was observed for Pleurotus pulmonarius and Lentinus squarossulus. Radial growth for both was supported by crude oil and AGO at all concentrations whereas growth on Engine oil (Fresh and Spent) was not observed beyond $10 \%$ concentration. There was significant reduction in radial growth as concentration of pollutants increased $(\mathrm{P}=0.05)$. @JASEM
\end{abstract}

Tons of hydrocarbons enter the environment whether introduced through oil spill, tank leakages or wastewater disposal. These pollutants are toxic and hazardous to life. Because of the enormous quantity of pollutants, their persistence and mobility in natural environments and their frequent toxicity, considerable attention has been directed to understanding their behavior in natural environments and devising means of bringing about their reduction or total eradication (Martin, 1983). Bioremediation is a biotechnological approach of rehabilitating areas degraded by pollutants or otherwise damaged through mismanagement of ecosystem. It is the ability of microorganisms to degrade or detoxify organic contaminated area by transforming undesirable and harmful substances into non-toxic compound. (Bioremediation overview, 2003). Polycyclic Aromatic Hydrocarbons (PAH) are major pollutants found in soil and sediments. Most of the restoration of $\mathrm{PAH}$ contaminated sites depends on the activity of bacteria. Whereas low molecular weights PAH are usually readily degraded, high molecular weights $\mathrm{PAH}$ resist extensive bacteria degradation in soil and sediment media, (Aust 1990; Mueller et al, 1991). White rot fungi would be expected to have greater access to poorly bioavailable substrates, since they secrete extracellular enzymes involved in the oxidation of complex aromatic compounds like lignin although the exact mechanisms by which lignin polymers are polymerized and mineralized is not fully understood (Sarkanen et al, 1991). The focus of this paper is to test the growth ability of three local edible mushrooms on crude oil, Automotive
Gasoline Oil (AGO), Engine Oil (Fresh and spent) in order to determine whether they are good biodegradation agents or not for the pollutants.

\section{MATERIALS AND METHODS}

Crude Oil (Bonny light, Agbada Spill) used for this study was obtained from the environmental department of SPDC Port Harcourt. AGO was obtained from AP Filling station Rumuibekwe, Port Harcourt. Spent Engine Oil was obtained from mechanic workshop in Woji Port- Harcourt. Fresh Engine Oil (Total rubia H SAE 40) was obtained from Total Filling Station, Port Harcourt. Spawns of Pleurotus pulmonarius, Pleurotus tuber- regium and Lentinus squarrosulus were obtained from Federal Institute of Industrial Research Oshodi, Lagos.

Preparation of fungal culture: The Spawn of Pleurotus pulmonarius, Pleurotus tuber- regium and Lentinus squarrosulus were opened and watered for fruiting. A young fruit (three days old) was thoroughly washed in water. It was cut lengthwise from the Cap with the aid of a sterilized scalpel. With the aid of a sterilized needle, a small piece of the internal tissue of the broken mushroom was cut and removed. The tissue was used to inoculate Potato Dextrose Agar (PDA) medium in Petri dishes. This was done for each of the mushrooms. The petri dishes were incubated at $30^{\circ} \mathrm{C}$ for 10 days. The pure culture was then sub cultured severally for use in this study. The culture of $P$. tuber-regium and L. squarrosulus were sub -

*Corresponding author: E-mail: greattayo@yahoo.co.uk 
cultured several times until adequate ones were obtained, for use in this study.

Preparation of potato dextrose agar: To prepare one liter $(1 \mathrm{~L})$ of Potato Dextrose Agar, two hundred grammes (200g) of potato was peeled, sliced and boiled until soft. It was strained through a fine sieve and then made up to one litre with distilled water. Fifteen grammes of agar (15g) and twenty grammes $(20 \mathrm{~g})$ of glucose were added. The conical flasks containing the mixture were plugged with cotton wool, covered with aluminum foil and sterilized in an autoclave at $121^{\circ} \mathrm{C}$ for $15 \mathrm{~min}$. The prepared PDA was dispensed into sterile $200 \mathrm{ml}$ conical flasks in measures of $142.5 \mathrm{ml}, 135 \mathrm{ml}$, $120 \mathrm{ml}$ and $105 \mathrm{ml}$. Crude oil was added to the liquid PDA in the following sequence $7.5 \mathrm{ml}, 15 \mathrm{ml}$, $30 \mathrm{ml}$ and $45 \mathrm{ml}$ respectively to give final concentrations of $5 \%, 10 \% 20 \%$ and $30 \%$ of crude oil in the mixture. The mixture was sterilized by autoclaving at $121^{\circ} \mathrm{C}$ for 15 minutes. After cooling, $10 \mathrm{ml}$ of the mixture was dispensed into Petri dishes and allowed to solidify. This procedure was repeated for each of the following pollutants: AGO, fresh Engine Oil and Spent Engine Oil. The control was prepared by not adding any pollutant in to PDA medium.

Inoculation of plates: Pure cultures of $\mathrm{Pp}, \mathrm{Pt}$ and Ls were inoculated into the different concentrations of PDA/pollutant mixture. Inoculation of each plate was done with the aid of a $1 \mathrm{~cm}$ diameter cork borer. This was used to introduce the mushrooms to the centre of the plates. Controls that have no pollutant were set up. Three replicates of each concentration were made for each of the three mushrooms. All the Petri dishes were incubated at room temperature $28 \pm 2^{\circ} \mathrm{C}$ for 10 days. Growth of the fungi was taken by measuring the mycelia spread from the center of the plates using a transparent plastic ruler.

\section{RESULTS}

The radial growth of P.pulmonarius, P.tuberregium and L. squarrosulus on PDA/ Pollutant mixture are systematically discussed. The mycelial growth of P.tuber-regium was observed to be the fastest among the three mushrooms. In the Petri dishes that contained no COIL, AGO, ENGOIL and SENGOIL, the mycelia of the three fungi covered $4.2,4.5$ and $4.1 \mathrm{~cm}$. respectively. The mycelia of the three test fungi grew on COIL and AGO at all concentrations. P.tuber-regium grew on ENGOIL and SENGOIL at all concentrations but Adedokun, O M; Ataga, A E the growth was considerably reduced compared to growth on COIL and AGO (Fig. Ia). However, the radial growth of P.pulmonarius and $\mathrm{L}$. squarrosulus were completely inhibited at concentration over 10\% of ENGOIL and SENGOIL (Figs. Ib and Ic). Generally, there was significant reduction in the radial growth $(\mathrm{P}=0.05)$ of the three test fungi as concentration of pollutants increased.

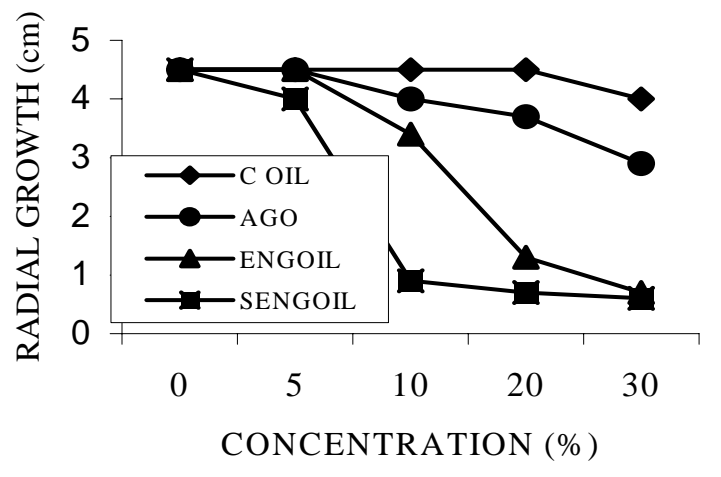

Fig Ia: Effects of different concentrations of COIL, AGO, ENGOIL and SENGOIL on the radial growth of Pleurotus pulmonarius (PP).

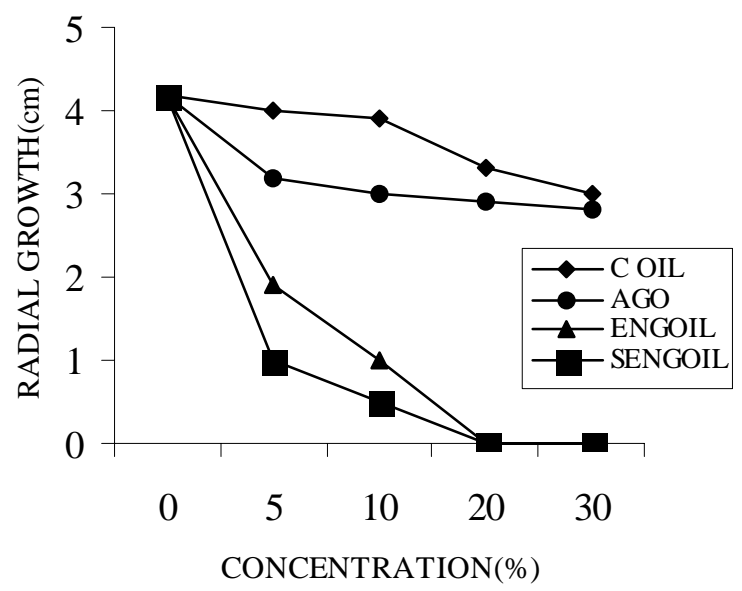

FIG Ib: Effects of different concentrations of COIL, AGO, ENGOIL and SENGOIL on the radial growth of Pleurotus tuber-regium (PT).

\section{DISCUSSION}

The tolerance of the mycelia of $\mathrm{P}$. tuber reguium, $P$. pulmonarius and $L$. squarrosulus of the pollutants, which served as treatments in this study, varied. The outstanding mycelia growth of $P$. tuber regium on all treatments and at all concentrations used, may be due to higher production of extra cellular enzymes that enabled it utilize the hydrocarbons faster than the other two fungi. $P$. pulmonarius and $L$. squarrosulus may also have 
this ability as they too grew at all concentrations on C. OIL and AGO. This agrees with the findings of Stamen (1999) that mycelial mats are used for bioremediation because mycelia produce extra cellular enzymes and acids that break down recalcitrant molecules such as; lignin and cellulose and that lignin peroxidases dismantle the long chains of hydrogen and carbon making them effective at breaking apart hydro carbon the base structure common to oils, petroleum products, pesticides, PCBS and many other pollutants.

The pattern of growth of mycelia of $P$. tuber -regium, $L$ squarrosulus and P. pulmonarius on Engine Oil (fresh and spent) may be due to the fact that Engine oil is just a single petroleum product and may contain chemical additives responsible for inhibiting growth. Although $P$. tuber-regium, grew at all concentrations

of fresh and spent Engine Oil, the growth is reduced compared with growth on C. OIL and AGO. Odjegba and Sadiq (2002) reported that Engine oil usually contains chemical additives, which include amines, phenols, benzene, calcium, zinc, barium, magnesium, phosphorus, sulphur and lead. They also reported that metals present in spent lubricating oil are not necessarily the same as those present in unused lubricant.

concentrations (\%) of pollutants.

The reduction in mycelial growth as concentration of pollutants increased could be due to the toxicity of pollutants as PDA in the mixture is significantly reduced and growth on PDA alone, (control-zero concentration) did well (Table I), covering almost the entire plates.

The ability of these mushrooms to tolerate the pollutants and grow on them, suggests they could be employed as bioremediation agents on sites contaminated by these pollutants. However, further studies should be carried out to determine the enzymes produced by each of these mushrooms.

\section{REFERENCES}

Aust, SD (1990). Degradation of Environ mental pollutants by Phanerocheae chrysosponium. Microb.Ecol. 20:197-209

Bioremediation overview (2003). http: // w w w. in tegra environmental.com /bior overnew.htm.

Bumpus, JA; Aust, SD (1987). Biodegradation of environmental pollutants by the white rot fungus Phanerocheae chrysosporium: involvement of the lignin degrading system. Bioassays 6:166-170.

Hammel, KE; Moen, MA (1991). Depolymerization of a synthetic lignin in vitro by lignin peroxidase. Enzyme micro. Technol. 13:15-18.

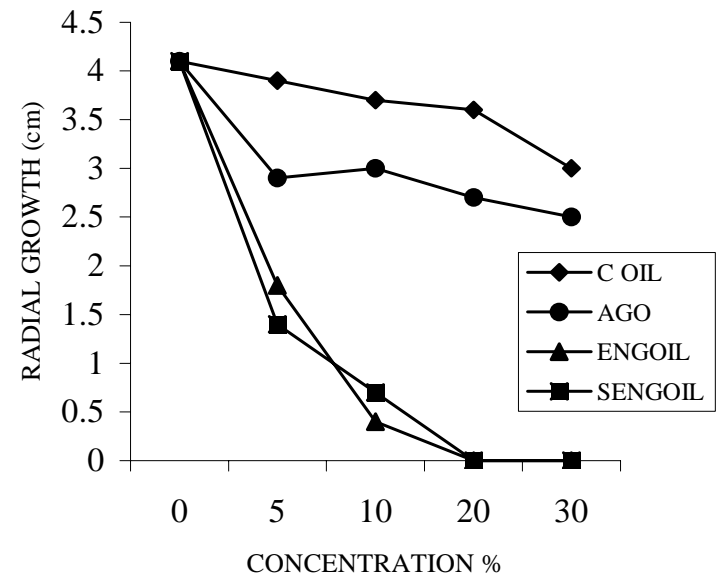

Fig.Ic Effects of different concentrations of COIL, AGO, ENGOIL and SENGOIL on the radial growth of Lentinus squarrosulus (LS).

Kirk, TK; Farrell, RI (1987) Enzymatic “Combustion”: the microbial degradation of lignin. Annu.Rev. Microbiol. 41:465 -505

Leahy, JG; Colwell, RR (1990). Microbial degradation of hydrocarbons in the environment. Microbiological reviews 54, 305 315.

Manilal, VB; Alexander, M (1991). Factors affecting the microbial degradation of phenanthrene in soil. Appl. microbial Biotechnol, 35:401 -405.

Martin, A (1983). Microbial Technologies to overcome environmental problems of persistent pollutants Ithaca NY USA.

Mueller, JG; Lantz, SE; Blattman, BO; Chapman, PJ (1991). Bench - scale evaluation of alternative biological treatment process for the remediation of pentachlorophenol and creosote - contaminated materials: solid phase bioremediation. Environ .Sci Technol. 25:1045-1055..

Odjegba, VJ; Sadiq, AO (2002) Effect of spent Engine Oil on the growth parameters, chlorophyll and protein levels of amarathus hybridus L. The Environmentalist. 22.23 - 28

Stamen, P (1999). Healing the planet with mushrooms. http://www.wholeearthmag.com/articlbin/275.html

Sarkanen, S; Razal, RA; Piccariello, T; Etsuo, Y; Lewis, NG (1991). Lignin peroxidases: toward a clarification of its role in vivo. J.Biol. Chem. 266:3634 -3636. 
Adedokun, O M; Ataga, A E 